\title{
Prevalence and determinants of depression among caregivers of children with leukaemia in Iraq
}

Noor Mohammed Lutfi ${ }^{1}$ and Faris Al Lami ${ }^{2}$

${ }^{1}$ Ministry of Health, Baghdad, Iraq, ${ }^{2}$ College of Medicine, University of Baghdad, Baghdad, Iraq (Correspondence to: Faris Al Lami: farislami@gmail.com)

\begin{abstract}
Background: Depression in caregivers of leukaemic children is usually overlooked and hence missed, as doctors mostly focused on patient's evaluation and condition. Early attention to symptoms of depression may help to prevent the development of a more serious depression over time.

Aims: This study was conducted to estimate the prevalence, assess severity and identify determinants of depressive disorder among caregivers of children with leukaemia in Baghdad, Iraq, 2014.

Methods: This cross sectional study was conducted on a convenience sample of caregivers of 250 leukaemia children aged $<15$ years admitted to Child Welfare Teaching Hospital, Baghdad, Iraq. Socio-demographic variables were collected and the presence of depressive disorder was assessed using the Arabic Version of Beck Depression Inventory II (BDI-II); those with a score of $>16$ were considered depressed.

Results: The prevalence of depression was $72 \%$ (95\% CI: 66-77.5\%); classified to $18.9 \%$ having borderline clinical depression, $36.7 \%$ moderate depression, $27.8 \%$ severe depression and $16.7 \%$ extreme depression. Presence of depression was significantly higher among younger age caregivers, disease duration of $>12$ months and frequent hospital admission.

Conclusions: The high prevalence of depression among care givers of leukaemia patients urge health care professionals to pay more attention to the psychological aspects of the families of leukaemia patients and ensure referring them for psychiatric support.

Keywords: depressive disorders, caregivers, leukaemia, determinants, Iraq

Citation: Lutfi NM; Al Lami F. Prevalence and determinants of depression among caregivers of children with leukaemia in Iraq. East Mediterr Health J. 2019;25(6):385-393. https://doi.org/10.26719/emhj.19.005

Received: 19/04/15; accepted: 11/01/18

Copyright (C) World Health Organization (WHO) 2019. Some rights reserved. This work is available under the CC BY-NC-SA 3.0 IGO license (https:// creativecommons.org/licenses/by-nc-sa/3.0/igo).
\end{abstract}

\section{Introduction}

Leukaemia is the most common malignant neoplasm in childhood, accounting for about $31 \%$ of all malignancies among children less than 15 years of age (1). In Iraq, the latest figures indicate a total leukaemia rate of 4.18 per 100000 among boys, and 2.07 per 100000 among girls during 2008-2009 (2). Since the late 20th century, the overall survival rate of Acute Myeloblastic Leukaemia (AML) has improved and reached $45-60 \%$ (3), while the 5 -year survival rate for children diagnosed with Acute Lymphoblastic Leukaemia (ALL) rose from $84 \%$ during 1990-1994 to 90\% during 2000-2005 (4).

A diagnosis of leukaemia reverberates around the family and has implications for all, not just the diseased child (5), and marks the beginning of social and psychological devastation for the whole family especially the mother. The length and intensity of the treatment can be as distressing as the disease itself, negatively affecting their functionality as parents and in turn the child's ability to handle the treatment (6). This makes children with leukaemia and their families require longterm help and support from various agencies, including the primary health care team.

The term family caregiver refers to an unpaid family member, friend or neighbour who provides care to an individual that has an acute or chronic condition and needs assistance to manage a variety of tasks, from bathing, dressing to taking medication (7). Care giving also involves a great deal of emotional support that may include listening, counseling and companionship (8). Today, one of the all-too silent health crises is caregiver depression. Early attention to symptoms of depression may help to prevent the development of a more serious depression over time (9), although stigma and lack of awareness of mental disorders lead to under-use of available mental health services (10).

It has been found that the younger the caregiver, the higher stress she or he experiences (11). The most important concern of the families was the provision of the necessary time and expenses (12). Parents of children with cancer suffered greater financial hardship than parents of children with other serious illness (13). Having other children to be looked after is an additional role for the caregiver that requires time and energy. The most time- and energy-consuming task performed by parents are the provision of emotional support to the ill child and supporting other children (14). Decrease in contact with others and planned activities and decreased time for social activities predicted distress in cancer caregivers (11). Continuation of a normal life is difficult for both the child and the mother due to economic burdens, problems at work, and restriction of social life (15). 
Caregivers need a range of support services to remain healthy, improve their caregiving skills and remain in their caregiving role. Support services include information, assistance, counseling, respite, home modifications or assistive devices, caregiver and family counseling, and support groups (9). A lot of studies evaluated the psychiatric impact of different chronic diseases on the patients themselves, but little is known about this problem among the caregivers, and even less in Iraq. The objectives of this study were to estimate the prevalence, assess severity and identify determinants of depression among caregivers of children with leukaemia in Children Welfare Hospital, Baghdad, Iraq, 2014.

\section{Methods}

This cross-sectional study was conducted on a convenience sample of caregivers of 250 leukaemia children aged $<15$ years admitted to Child Welfare Teaching Hospital during March-June, 2014, and who accepted to participate. For each leukaemic child, the primary care giver accompanying the child was included. Verbal approval was granted from all participants.

\section{Data collection}

All information was obtained from the caregivers using a questionnaire that was filled through direct interview and gathered socio-demographic data of the caregiver (age, sex, residence, employment status, marital status, educational level, income, relationship to the patient and counts of other children to be looked after) and the disease status of the leukaemic child (age of onset of disease in years, duration of disease in months, and number of hospital admissions). Assessment of presence and severity of depression among caregivers were evaluated using the Arabic version of Beck Depression Inventory II (BDIII) questionnaire. This questionnaire is the most frequently used screening instrument in clinical work and research on depression (16-19), created by Aaron T. Beck, and consists of 21-multiple choice survey measuring the mood of the participants for the previous two weeks. It was also proved useful for measuring the severity of depression (17). The easy applicability and psychometric soundness of this scale have popularized its use in a variety of samples and in health care setting worldwide (20).

The scores obtained from each question ranges from $0-3$, the total score was calculated and it measures the presence and severity of cognitive and somatic symptoms of depression on a scale from $0-63$. A score of $0-16$ is considered normal, 17-20: borderline clinical depression, 21-30: moderate depression, 31-40: severe depression and over 40 : extreme depression (19). A score of $\geq 17$ is considered depression.

\section{Statistical analysis}

Statistical Package for Social Science (SPSS 19) was used for data entry and analysis. Chi square test ( $\mathrm{X}^{2}$-test) of independence was used to test association between categorical data. Logistic regressions analysis was used to identify the independent risk factors of depression (as outcome variable), with calculation of the Odds Ratio (OR) and its 95\% Confidence Interval (CI). Statistical significance was considered whenever $P$-value was equal or less than 0.05 .

\section{Results}

A total of 250 caregivers (all were females) were included. The age range was $18-54$ years, the mean age ( \pm standard deviation) was $34( \pm 8.7)$ years. Caregivers living in Baghdad represent $56.8 \%$, the remaining were from other governorates. The majority of caregivers were housewives $(88.4 \%, 221)$, and 92\% (229) were married. (Table 1)

Secondary school and primary school graduates constituted $37.6 \%$ (94) and 36\% (90) respectively, while illiterate represents $18.4 \%(46)$. Caregivers with inadequate income level were $58.4 \%$ (146). Mother caregivers constituted the vast majority $(88.8 \%, 222)$, while grandmothers and aunts constituted the remaining $11.2 \%$ (28). Caregivers who were caring for $3+$ children constituted $57.2 \%$ (143) and those with no other children to care for constituted $11.6 \%$ (29) (Table 1).

The proportion of studied children who developed leukaemia under five years old was 60\% (150) (Table 2). The mean age $( \pm S D)$ was $4.4( \pm 2.3)$ years. The duration of leukaemia of more than 12 months was reported in $35.6 \%$ (89) of leukaemic children. Leukaemic children who had $6+$ hospital admissions constituted 36\% (90), and those mitted for the first time constituted 31.2\% (78) (Table 2).

According to the results of BDI-II questionnaire, $72 \%$ (180) of the study sample has depression; 95\% CI 66.0$77.5 \%$. Around $37 \%$ (92) of those with depression had moderate depression, followed by those having severe depression $(27.8 \%, 70)$. Only $16.7 \%$ (42) had extreme severe depression.

The prevalence of depression was highest among youngest age group $(<30$ years $=80.6 \%, 83)$ and decrease with increasing age to reach $55.2 \%$ (32) among the oldest age group (40+ years). The association between age and depression was statistically significant $(P=0.003)$ (Table 1).

The prevalence of depression among currently married caregivers was $73.8 \%$ (169). Being married was significantly associated with depression $(P=0.036)$. Also, the prevalence of depression was significantly higher among caregivers with $3+$ other children to be looked after $(87.3 \%, 112)$ compared to $58.6 \%(17)$ for those with no other children to look after $(P=0.029)$ (Table 1).

The prevalence of depression was significantly higher among caregivers of leukaemic children with duration of leukemia of more than 12 months $(87.6 \%, 78)$ as compared to those with the duration of $\leq 12$ months $(63.4 \%, 102)$ $(P=0.000)$ (Table 2).

The prevalence of depression was highest at the two extreme categories of number of hospital admission; $79.5 \%$ (62) for those with first admission and $82.2 \%$ (74) for those with more than six admissions. The association 


\begin{tabular}{|c|c|c|c|c|c|c|c|c|}
\hline \multirow{2}{*}{$\begin{array}{l}\text { Socio-demographic } \\
\text { variables }\end{array}$} & \multicolumn{2}{|c|}{ Depressed } & \multicolumn{2}{|c|}{ Not depressed } & \multicolumn{2}{|c|}{ Total } & \multirow[t]{2}{*}{$\mathbf{X}^{2}$} & \multirow[t]{2}{*}{ PValue } \\
\hline & $\mathbf{N}=\mathbf{1 8 0}$ & $\%$ & $N=70$ & $\%$ & $\mathbf{N}=\mathbf{2 5 0}$ & $\%$ & & \\
\hline \multicolumn{9}{|l|}{ Age group (years) } \\
\hline$<30$ & 83 & 80.6 & 20 & 19.4 & 103 & 41.2 & \multirow[t]{3}{*}{12.0} & \multirow[t]{3}{*}{0.003} \\
\hline $30-39$ & 65 & 73.0 & 24 & 27.0 & 89 & 35.6 & & \\
\hline $40+$ & 32 & 55.2 & 26 & 44.8 & 58 & 23.2 & & \\
\hline \multicolumn{9}{|l|}{ Residence } \\
\hline Baghdad & 102 & 71.8 & 40 & 28.2 & 142 & 56.8 & \multirow[t]{2}{*}{0.005} & \multirow[t]{2}{*}{0.95} \\
\hline Other governorates & 78 & 72.2 & 30 & 27.8 & 108 & 43.2 & & \\
\hline \multicolumn{9}{|l|}{ Employment status } \\
\hline Housewife & 156 & 70.6 & 65 & 29.4 & 221 & 88.4 & \multirow[t]{2}{*}{1.884} & \multirow[t]{2}{*}{0.17} \\
\hline Currently employed & 24 & 82.8 & 5 & 17.2 & 29 & 11.6 & & \\
\hline \multicolumn{9}{|l|}{ Marital status } \\
\hline Currently married & 169 & 73.8 & 60 & 26.2 & 229 & 91.6 & \multirow[t]{2}{*}{4.377} & \multirow[t]{2}{*}{0.036} \\
\hline $\begin{array}{l}\text { Divorced/widowed/ } \\
\text { single }\end{array}$ & 11 & 52.4 & 10 & 47.6 & 21 & 8.4 & & \\
\hline \multicolumn{9}{|l|}{ Educational level } \\
\hline Illiterate & 30 & 65.2 & 16 & 34.8 & 46 & 18.4 & \multirow[t]{4}{*}{5.062} & \multirow[t]{4}{*}{0.17} \\
\hline Primary school & 60 & 66.7 & 30 & 33.3 & 90 & 36.0 & & \\
\hline Secondary school & 74 & 78.7 & 20 & 21.3 & 94 & 37.6 & & \\
\hline Vocational (institute/university) & 16 & 80.0 & 4 & 20.0 & 20 & 8.0 & & \\
\hline \multicolumn{9}{|l|}{ Income } \\
\hline Adequate & 71 & 68.3 & 33 & 31.7 & 104 & 41.6 & \multirow[t]{2}{*}{1.229} & \multirow[t]{2}{*}{0.27} \\
\hline Inadequate & 109 & 74.7 & 37 & 25.3 & 146 & 58.4 & & \\
\hline \multicolumn{9}{|l|}{ Relationship to the patient } \\
\hline Mother & 162 & 73.0 & 60 & 27.0 & 222 & 88.8 & \multirow[t]{2}{*}{0.931} & \multirow[t]{2}{*}{0.33} \\
\hline Grandmother/aunt & 18 & 64.3 & 10 & 35.7 & 28 & 11.2 & & \\
\hline \multicolumn{9}{|c|}{ No. of other children to be looked after } \\
\hline 0 & 17 & 58.6 & 12 & 41.4 & 29 & 11.6 & \multirow[t]{3}{*}{7.1029} & \multirow[t]{3}{*}{0.029} \\
\hline $1-2$ & 51 & 65.4 & 27 & 34.6 & 78 & 31.2 & & \\
\hline $3+$ & 112 & 87.3 & 31 & 12.7 & 143 & 57.2 & & \\
\hline
\end{tabular}

Table 2: Distribution of the study group by depression and selected disease characteristics

\begin{tabular}{|c|c|c|c|c|c|c|c|c|}
\hline \multirow[t]{2}{*}{ Disease Characteristics } & \multicolumn{2}{|c|}{ Depressed } & \multicolumn{2}{|c|}{ Not depressed } & \multicolumn{2}{|c|}{ Total } & \multirow[t]{2}{*}{$\mathbf{X}^{2}$} & \multirow[t]{2}{*}{ P Value } \\
\hline & $\mathrm{N}=\mathbf{1 8 0}$ & $\%$ & $\mathrm{~N}=70$ & $\%$ & $\mathrm{~N}=\mathbf{2 5 0}$ & $\%$ & & \\
\hline \multicolumn{9}{|l|}{ Age of onset (years) } \\
\hline$<5$ years & 109 & 72.7 & 41 & 27.3 & 150 & 60.0 & \multirow[t]{2}{*}{0.083} & \multirow[t]{2}{*}{0.77} \\
\hline $5+$ years & 71 & 71.0 & 29 & 29.0 & 100 & 40.0 & & \\
\hline \multicolumn{9}{|c|}{ Duration of leukaemia (month) } \\
\hline$<12$ months & 102 & 63.4 & 59 & 36.6 & 161 & 64.4 & \multirow[t]{2}{*}{16.769} & \multirow[t]{2}{*}{$<0.0001$} \\
\hline$>12$ months & 78 & 87.6 & 11 & 12.4 & 89 & 35.6 & & \\
\hline \multicolumn{9}{|l|}{ Count of hospital admissions } \\
\hline First admission & 62 & 79.5 & 16 & 20.5 & 78 & 31.2 & \multirow[t]{3}{*}{20.517} & \multirow[t]{3}{*}{$<0.001$} \\
\hline $2-5$ & 44 & 53.7 & 38 & 46.3 & 82 & 32.8 & & \\
\hline $6+$ & 74 & 82.2 & 16 & 17.8 & 90 & 36.0 & & \\
\hline
\end{tabular}


between number of hospital admissions and depression was statistically significant $(P<0.001)$ (Table 2$)$.

A cross-classification was made for caregivers with severe/extreme depression versus moderate/borderline depression by a number of socio-demographic variables and disease status of the leukaemic children. Severe/ extreme depression was significantly higher among youngest age group $(<30$ years) $(61.4 \%, 51)(P<0.001)$; those with inadequate income level $(51.4 \%, 56)(P=0.02)$; and being mothers $(46.9 \%, 76)(P=0.046)$. (Table 3) The prevalence of severe/ extreme depression was significantly higher among caregivers of leukaemic children whose age of onset of leukaemia was below 5 years old $(50.5 \%, 55)(P=0.044)$ (Table 4$)$.

Logistic regression analysis was applied considering the presence of depression as the outcome variable; and the socio-demographic and disease status variables as independent variables in the model. The model was statistically significant and able to accurately predict group membership according to the outcome (depressed vs. not depressed) with an accuracy level of $78.4 \%$. Three explanatory variables had a statistically significant association with the risk of having depression. These variables were:

- age; youngest age group (<30 years) with Odds Ratio $(\mathrm{OR})=6.69 ; 95 \%$ Confidence Interval $(\mathrm{CI}): 1.91-22.77$ $(P=0.003)$;

- disease duration; $>12$ months' duration with $\mathrm{OR}=6.225$; 95\% CI: $2.399-16.150$ ( $P=0.000)$; and

- number of hospital admission; first admission with OR $=9.17 ; 95 \%$ CI: $1.67-49.13(P=0.01)$ (Table 5).

Table 3: Distribution of depressed group by severity of depression and selected socio-demographic variables

\begin{tabular}{|c|c|c|c|c|c|c|c|c|}
\hline \multirow[t]{2}{*}{$\begin{array}{l}\text { Socio-demographic } \\
\text { variables }\end{array}$} & \multicolumn{2}{|c|}{$\begin{array}{l}\text { Borderline disease / } \\
\text { moderate depression }\end{array}$} & \multicolumn{2}{|c|}{$\begin{array}{c}\text { Severe/extreme } \\
\text { depression }\end{array}$} & \multicolumn{2}{|c|}{ Total } & \multirow[t]{2}{*}{$\mathrm{X}^{2}$} & \multirow[t]{2}{*}{ PValue } \\
\hline & $\mathrm{N}=100$ & $\%$ & $\mathbf{N}=\mathbf{8 0}$ & $\%$ & $\mathrm{~N}=\mathbf{1 8 0}$ & $\%$ & & \\
\hline \multicolumn{9}{|l|}{ Age group (years) } \\
\hline$<30$ & 32 & 38.6 & 51 & 61.4 & 83 & 46.1 & \multirow[t]{3}{*}{18.494} & \multirow[t]{3}{*}{$<0.001$} \\
\hline $30-39$ & 44 & 67.7 & 21 & 32.3 & 65 & 36.1 & & \\
\hline $40+$ & 24 & 75.0 & 8 & 25.0 & 32 & 17.7 & & \\
\hline \multicolumn{9}{|l|}{ Residence } \\
\hline Baghdad & 55 & 53.9 & 47 & 46.1 & 102 & 56.6 & \multirow[t]{2}{*}{0.255} & \multirow[t]{2}{*}{0.61} \\
\hline Other governorates & 45 & 57.7 & 33 & 42.3 & 78 & 43.3 & & \\
\hline \multicolumn{9}{|l|}{ Employment status } \\
\hline Housewife & 87 & 55.8 & 69 & 44.2 & 156 & 86.6 & \multirow[t]{2}{*}{0.022} & \multirow[t]{2}{*}{0.88} \\
\hline Currently employed & 13 & 54.2 & 11 & 45.8 & 24 & 13.3 & & \\
\hline \multicolumn{9}{|l|}{ Marital status } \\
\hline Currently married & 92 & 54.4 & 77 & 45.6 & 169 & 93.8 & \multirow[t]{2}{*}{1.399} & \multirow[t]{2}{*}{0.24} \\
\hline Divorced/widowed/single & 8 & 72.7 & 3 & 27.3 & 11 & 6.1 & & \\
\hline \multicolumn{9}{|l|}{ Educational level } \\
\hline Illiterate & 13 & 43.3 & 17 & 56.7 & 30 & 16.6 & \multirow[t]{4}{*}{3.016} & \multirow[t]{4}{*}{0.39} \\
\hline primary school & 34 & 56.7 & 26 & 43.3 & 60 & $33 \cdot 3$ & & \\
\hline Intermediate/secondary school & 42 & 56.8 & 32 & 43.2 & 74 & 41.1 & & \\
\hline Vocational (institute/university) & 11 & 68.8 & 5 & 31.3 & 16 & 8.8 & & \\
\hline \multicolumn{9}{|l|}{ Income } \\
\hline Adequate & 47 & 66.2 & 24 & 33.8 & 71 & 39.4 & \multirow[t]{2}{*}{$5 \cdot 377$} & \multirow[t]{2}{*}{0.02} \\
\hline Inadequate & 53 & 48.6 & 56 & 51.4 & 109 & 60.5 & & \\
\hline \multicolumn{9}{|l|}{ Relationship to the patient } \\
\hline Mother & 86 & 53.1 & 76 & 46.9 & 162 & 90.0 & \multirow[t]{2}{*}{4.0} & \multirow[t]{2}{*}{0.046} \\
\hline Grandmother/aunt & 14 & 77.8 & 4 & 22.2 & 18 & 10.0 & & \\
\hline \multicolumn{9}{|c|}{ Count of other children to be looked after } \\
\hline 0 & 11 & 64.7 & 6 & $35 \cdot 3$ & 17 & 9.4 & \multirow[t]{3}{*}{2.630} & \multirow[t]{3}{*}{0.26} \\
\hline $1-2$ & 32 & 62.7 & 19 & 37.3 & 51 & 28.3 & & \\
\hline $3+$ & 57 & 50.9 & 55 & 49.1 & 112 & 62.2 & & \\
\hline
\end{tabular}




\begin{tabular}{|c|c|c|c|c|c|c|c|c|}
\hline \multirow[t]{2}{*}{ Disease Characteristics } & \multicolumn{2}{|c|}{$\begin{array}{l}\text { Borderline disease / } \\
\text { moderate depression }\end{array}$} & \multicolumn{2}{|c|}{$\begin{array}{c}\text { Severe/extreme } \\
\text { depression }\end{array}$} & \multicolumn{2}{|c|}{ Total } & \multirow[t]{2}{*}{$\mathbf{X}_{2}$} & \multirow[t]{2}{*}{ PValue } \\
\hline & $\mathrm{N}=100$ & $\%$ & $\mathbf{N}=\mathbf{8 0}$ & $\%$ & $\mathbf{N}=\mathbf{1 8 0}$ & $\%$ & & \\
\hline \multicolumn{9}{|l|}{ Age of onset (years) } \\
\hline$<5$ years & 54 & 49.5 & 55 & 50.5 & 109 & 60.5 & \multirow[t]{2}{*}{4.048} & \multirow[t]{2}{*}{0.044} \\
\hline $5+$ years & 46 & 64.8 & 25 & 35.2 & 71 & 39.4 & & \\
\hline \multicolumn{9}{|l|}{ Duration of leukemia (month) } \\
\hline$<12$ months & 59 & 57.8 & 43 & 42.2 & 102 & 56.7 & \multirow[t]{2}{*}{0.499} & \multirow[t]{2}{*}{0.48} \\
\hline$>12$ Months & 41 & 52.6 & 37 & 47.4 & 78 & 43.3 & & \\
\hline \multicolumn{9}{|l|}{ Count of hospital admissions } \\
\hline First admission & 33 & 53.2 & 29 & 46.8 & 62 & 34.4 & \multirow[t]{3}{*}{3.902} & \multirow[t]{3}{*}{0.14} \\
\hline $2-5$ & 30 & 68.2 & 14 & 31.8 & 44 & 24.4 & & \\
\hline $6+$ & 37 & 50.0 & 37 & 50.0 & 74 & 41.1 & & \\
\hline
\end{tabular}

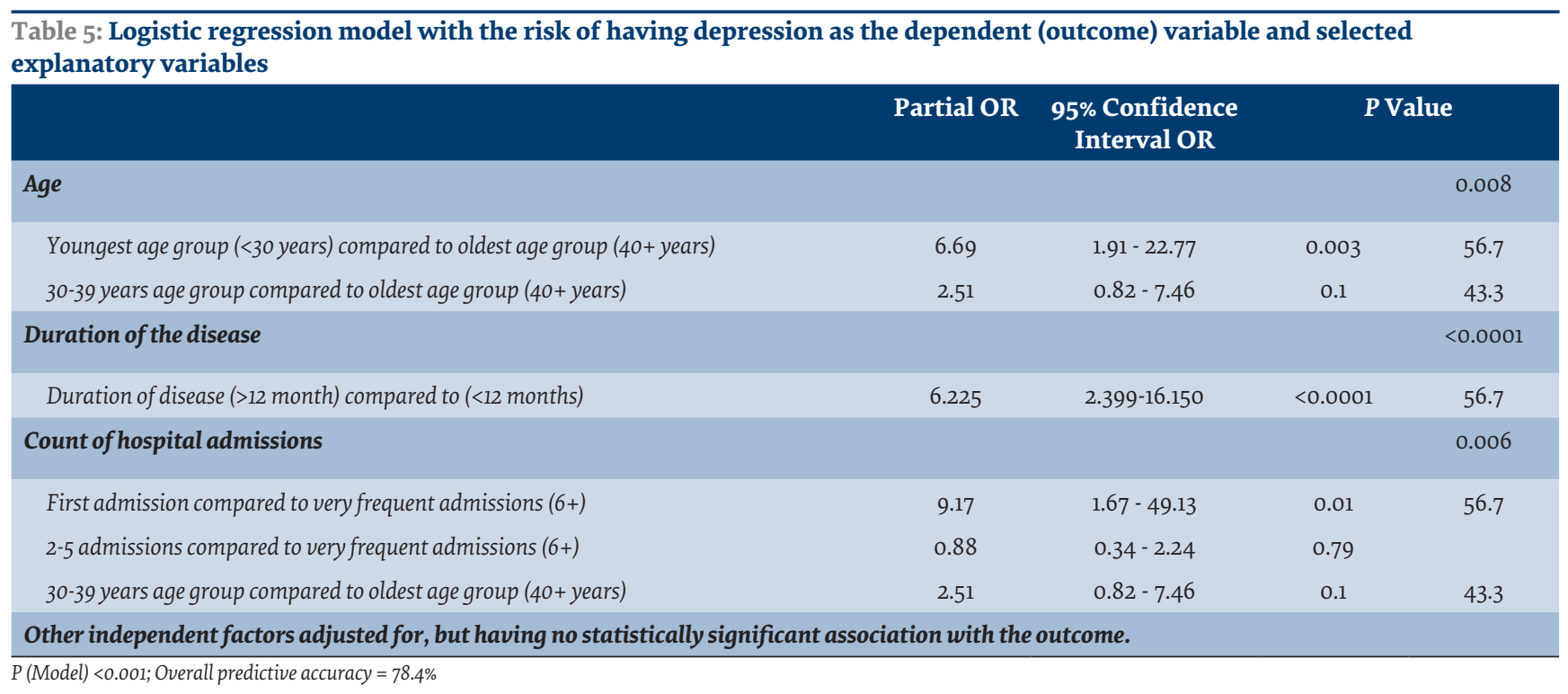

\section{Discussion}

Global and domestic media reports have emerged since the 1990s, highlighting the high cancer rate in Iraq. The incidence rate of all types leukaemia has risen substantially in children less than 15 years old (21). Most of the studies about caregiver depression were conducted in western countries, which may be different from elsewhere (7).

In this study the prevalence of depression based on BDI-II score was much higher than the prevalence reported in Iraq Mental Health Survey (IMHS), 20062007. The life time prevalence of any mental disorder in IMHS was $18.8 \%$ and Major Depressive Disorder (MDD) was the second most common disorder (7.2\%) after anxiety disorders $(13.8 \%)$. The 12-month prevalence of any disorder was $13.6 \% ; 21.9 \%$ of them considered serious and MDD was the most common disorder among this group (51\%) with no significant sex difference (22). In Iraq
Family Health Survey, around 35.5\% of respondents were considered as having significant "psychological distress". The prevalence was higher among females (40.4\%) than males (30.4\%) (23). Among attendees of primary healthcare centres in Baghdad, the prevalence of mental illness and depression was $36.8 \%$ and $18.3 \%$, respectively (24). Lower figures were reported in Nassiyriah City, south Iraq, where the prevalence of mental illnesses was $18 \%$ and the prevalence of depression was $10.8 \%$ (25).

The high prevalence of depression among caregivers in this study is consistent with a study in Pakistan, 2014, on mothers with children having cancer where $78 \%$ of the mothers were depressed (20); the majority had mild depression (69\%). A similar high prevalence of depression was noted in a study in Turkey, 2009, on mothers of children with leukaemia where $88 \%$ of mothers had depression, but the majority had major depression (61.5\%) (26). In the Islamic Republic of Iran, a study conducted in 
2014 showed a high prevalence of depression (91\%) among caregivers of children with cancer; the majority had mild depression (69\%) (16). In Korea, 2013, the prevalence of depression among family caregivers of cancer patients was $82.2 \%$, with the majority reporting mild depression $(40.4 \%)(27)$.

The prevalence of depression was high among the youngest age group of caregivers, which is consistent with Mathews et al., 2003 (11) study and a study done in Turkey in 2011 (28), and may reflect the inadequate experience of young mothers. The high prevalence of depression among caregivers with large number of other children to look after is similar to findings of studies conducted in Turkey, 2011 (28), and the United States of America, 2006 (29). Additional parenting role increases distress experienced by the caregiver.

Disease duration of more than 12 months was a significant risk factor for caregiver depression. Similar findings were reported in a study conducted in Sweden, which showed that mothers of children of newly diagnosed cancer, in active cancer and 1-year post diagnosis, reported more depressive symptoms than mothers of children undergoing active cancer therapy (30). The prevalence of depression was highest at the two extreme categories of number of hospital admissions. The first admission represents the time of shock, and more than six admissions represent the period of intensive chemotherapy. Some children need more frequent hospital admissions because they have frequent myelosuppression (31).

Severe/extreme depression was highest among the youngest age group; a finding consistent with a Turkish study (28) which also found that the younger the age of the caregiver the higher his/her level of depressive symptoms. Also, severe/extreme depression was more among those with inadequate income level. Family income was associated with caregiver depressive symptoms and the majority of depressed caregivers belong to the low socioeconomic class $(28,32)$. Mothers were more likely to have severe/extreme depression than non-mother caregivers due to the heavy emotional burden imposed on the mother of a leukaemic child, and other responsibilities that have to be managed by the mother for other children, her husband and house management. Also, severe/extreme depression was higher among mothers caring for children who develop the disease below 5 years of age. Emotional trauma and fear about the child's future could be behind this finding.

In this study, only the mothers of children with leukaemia were included, since the age limit of patients admitted to the paediatric hospitals in Iraq is 15 years and consequently, for cultural reasons, only mothers or other female caregivers are allowed to stay with the patients. Many studies conducted in other countries had included fathers and mothers of children diagnosed with leukaemia and other cancers. These studies, which included systematic review and meta-analysis, revealed higher prevalence of different types of mental disorders such as depression, anxiety and post-traumatic stress disorders among mothers as compared to fathers (32-38). Still, few studies did not show such a gender difference (39-41).

\section{Limitations}

As this was a cross-sectional study, any casual relationships cannot be inferred. Also, most of the caregivers in this study were unemployed; this had made the comparison by employment not feasible. Lastly, estimating the adequacy of family income was subjective and depended on the caregivers' responses.

\section{Conclusion}

The prevalence of depressive disorders among caregivers of leukaemic children was quite high, particularly among young mothers caring for children with disease duration of more than a year and those with frequent hospitalization. Health care professionals need to pay more attention to the psychological aspects of the families of leukaemia patients and ensure provision of psychosocial counseling and support as part of the overall management. The Iraqi Ministry of Health needs to take the initiative for the provision of comprehensive psychosocial support to the families caring for patients with chronic diseases and disabilities. Nursing schools can play a pivotal role in developing a cadre specialized in the provision of this type of support.

\section{Acknowledgments}

The study reported in this manuscript has been implemented after approval of the Ministry of Health, Iraq, and the Iraqi Board of Medical specialization.

Funding: None

Competing interests: None declared. 


\section{Prévalence et déterminants de la dépression chez les aidants d'enfants atteints de leucémie en Iraq}

\section{Résumé}

Contexte : La dépression chez les aidants d'enfants leucémiques est souvent négligée et donc non diagnostiquée, les médecins se concentrant la plupart du temps sur l'évaluation et l'état des patients. Une attention précoce accordée aux symptômes de la dépression pourrait permettre de prévenir le développement d'un stade plus avancé de cette affection.

Objectifs : La présente étude a été conduite dans le but d'estimer la prévalence, d'évaluer la sévérité et d'identifier les déterminants des troubles dépressifs chez les aidants d'enfants atteints de leucémie à Bagdad (Iraq) en 2014.

Méthodes : La présente étude transversale a été réalisée sur un échantillon de commodité de 250 aidants d'enfants leucémiques âgés de moins de 15 ans admis au Centre hospitalier universitaire pour la protection de l'enfance à Bagdad. Les variables socio-démographiques ont été recueillies et la présence de troubles dépressifs a été évaluée à l'aide de la version arabe de l'Inventaire de dépression de Beck II (BDI-II). Les répondants ayant un score supérieur à 16 étaient considérés comme dépressifs.

Résultats : La prévalence de la dépression était de $72 \%$ (IC à $95 \%$ : 66\%-77,5\%), parmi lesquels 18,9\% ont été diagnostiqués en dépression clinique limite, $36,7 \%$ en dépression modérée, $27,8 \%$ en dépression sévère et $16,7 \%$ en dépression extrême. La présence de cette affection était significativement plus élevée parmi les aidants plus jeunes ; elle durait généralement plus de 12 mois et nécessitait des hospitalisations fréquentes.

Conclusions: La prévalence élevée de la dépression parmi les aidants de patients leucémiques doit inciter les professionnels de la santé à accorder une attention plus soutenue à l'état psychologique des familles des patients et à s'assurer qu'elles soient orientées en vue de bénéficier d'un soutien psychiatrique.

$$
\begin{aligned}
& \text { معدل انتشار الاكتئاب بين القائمين على رعاية الأطفال المصابين بسرطان الدم (اللوكيميا) والعوامل المحددة له في } \\
& \text { العراق } \\
& \text { نور محمد لطفي، فارس العلمي } \\
& \text { الخلاصة }
\end{aligned}
$$

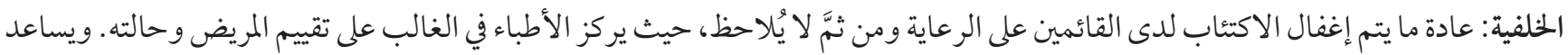

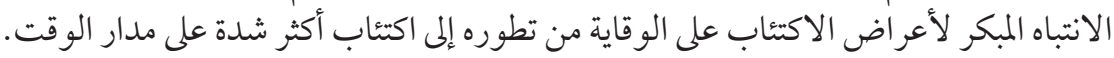

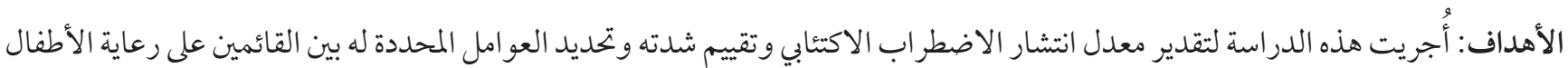

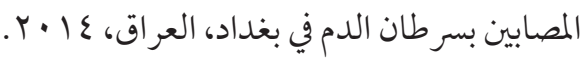

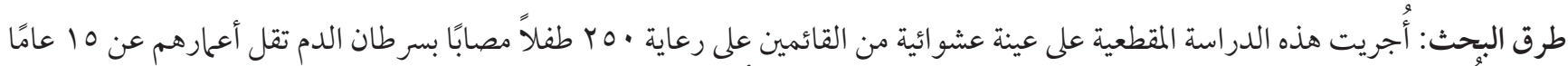

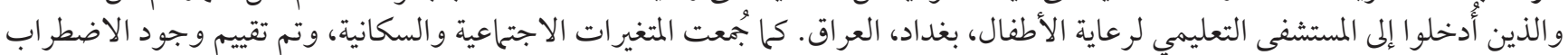

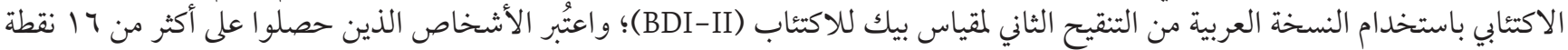

$$
\begin{aligned}
& \text { مصابين بالاكتئاب. }
\end{aligned}
$$

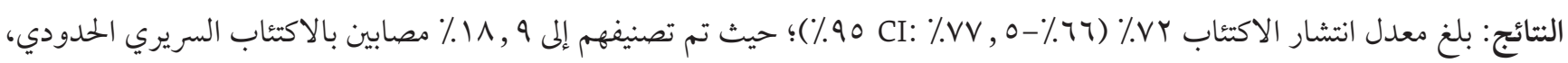

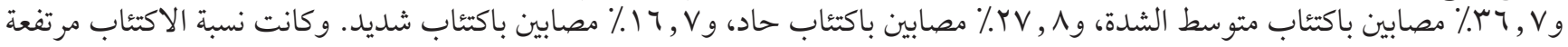

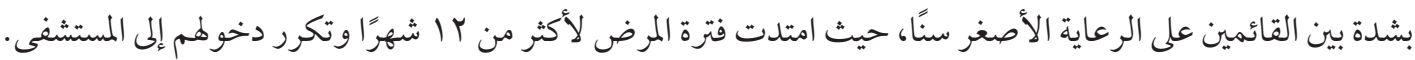

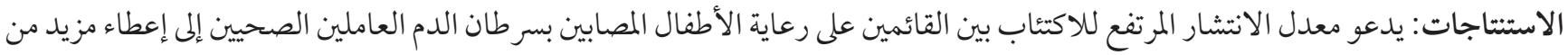

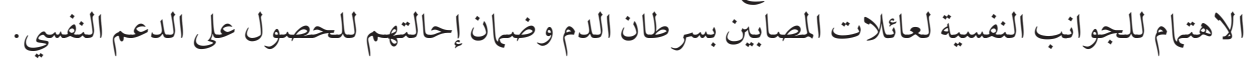

\section{References}

1. Robert M, Bonita F, Joseph W, Nina F, Richard E. Nelson's Textbook of Pediatrics ,19th edition. Philadelphia: Elsevier Saunders; 2011.

2. Alrudainy LA, Hassan JG, Salih HM, Abbas MK, Majeed AA. Time Trends and Geographical Distribution of Childhood Leukemia in Basrah, Iraq, from 2004 to 2009. SQU Med j, May 2011, 11, (2):215-20

3. Tomizawa D, Tabuchi K, Kinoshites A, Hanada R, Kigasawa H, Tsukimotol, et al. Repetitive cycle of high-dose cytarabine are effective for childhood acute myeloid leukemia: Long Term Outcome of the Children with AML treated on Two Consecutive Trials of Tokyo Children's Cancer Study Group. Pediatr Blood Cancer. Aug 2007;49(2):127-32 
4. Hunger SP, Lu X, Devidas M, Camitta BM, Gaynon PS, Winick NJ, et al. Improved Survival for children and Adolescents with Acute Lymphoblastic leukemia between 1990 and 2005. A Report from the Children's Oncology Group. J Clin Oncol. 2012 May 10; 30 (14):1663-9.

5. Foresteir E, Shmeigelow K. The Incidence Peaks of the Childhood Acute Leukemia Reflects Specific Cytogenetic Aberrations. J Pediatr Hematol Oncol. 2006 Aug; 28 (8):486-95.

6. Steele RG, Dryer ML, Phipps S. Patterns of maternal distress among children with cancer and their association with child emotional and somatic distress. J Pediatr Psychol. Oct 2004; 29(7):507-517

7. Kochaki N, Mohajjel A, Hassankhani H, Sannat Z. A brief review on patient caregiver studies in Iran. International Research Journal of Applied and Basic Sciences. 2013;5(8):999-1001

8. Drentia, P. Caregiving. In G. Ritzer (ED). Blackwell Encyclopedia of Psychology. Blackwell publishing. Blackwell reference online. 2007, June 13 (http://www.blackwelreference.com/,accessed 10/8/2014)

9. Family caregiver Alliance. Caregiver depression: A Silent Health Crisis Family Caregiver Alliance, National Center on Caregiving, 2002:(www.caregiver.org/,accessed 15/08/2014)

10. Rix S, Paykel ES, Lelliot P, Freeling P, Gask L, Hart D. The Defeat Depression Campaign: psychiatry in the public arena. Am J Psychiatry. 1997; 154:59-65

11. Mathews B.A., Baker F., Spillers R.E. Family caregivers and indicators of cancer-related distress. Psychology, Health and Medicine, 2003;8:45-57

12. Rocha-Garcia, A, Rio, AA, Hernandez-Pena, P, Martinez-Garcia, Marin-Patomares, M., et al. The emotional response of families to children with leukemia at the lower socio-economic level. In Central Mexico: A preliminary report. Psycho-Oncology, 2003, 12, 78-90.

13. Heath JA, Lintuuran RM, Rigguto G, Tikottian N, McCarthy M. Childhood cancer: Its impact and financial costs for Australian families. Pediatr Hematol Oncol. 2006; 23; 439-48.

14. Savavarsdottir, EK. Caring for a child with cancer. A longitudinal Perspectgive Journal of Advanced Nursing, 2005,50, 153-161

15. Earle, EA, Clarke, SA, Eister, C, Sheppard L: Building a new normality: Mother's experience of caring for a child with acute lymphoblastic leukemia. Child Care Health and Development, 2007 Mar; 33(2), 155-60.

16. Kholasehzadeh G, Shiryazadi SM, Neamatzadeh H, Ahmadi N. Depression levels among mothers of children with leukemia. Iranian Journal of Pediatric Hematology and Oncology. 2014: 4(3): 109-113.

17. Beck depression Inventory, (www.depression.wikia.com/accessed, 01/09/2014).

18. Wamg YP, Gorenstein C. Assessment of depression in medical patients: A systematic review of the utility of the Beck Depression Inventory-II. Clinics. 2013; 68 (9): 1274-1278.

19. Singh A, Lal A, Shekhar. Prevalence of Depression Among Medical Students of a Private Medical College in India. Online J Health Allied Scs. 2010;9(4):8

20. Ghufran M, Andrades M, NanjiK. Frequency \& severity of depression among mothers of children with cancer: Results from a teaching hospital in Karachi, Pakistan. BJMP. 2014;7(1): a701.

21. AL-Hashimi M and Wang X. Trends of leukemia in Ninwa/ Iraq. Clinical and Experimental Medical Sciences. 2013;1(8):353-362. HIKARI Ltd, (www.m-hikari.com/accessed, 25/07/2014).

22. World Health Organization, Iraq Mental Health Survey 2006/7 Report.

23. Iraq Ministry of Health, Iraq Ministry of Planning and Development Cooperation, World Health Organization. Iraq Family Health Survey 2006/7 Report.

24. Salman T, Al Lami F, Rhema S. Prevalence and determinants of mental illnesses among a sample of adult patients attending primary health care centers in Baghdad, Iraq. Accepted for publication in Iraqi Postgraduate Medical Journal.

25. Hussein AH, Saadoon, AA, Prevalence of anxiety and depressive disorders among Primary Health Care Attendees in Al Nassiryah, Iraq. Journal of Muslim Mental Health, 2006, 1, 171-6

26. Erkan S, Kaplan Y. A study on the depression levels of mothers of leukemic children. Pak J Soc Sci. 2009 Sept;6(1):42-47.

27. Park B, Kim SY, Shin JY, Sanson-Fischer RW, Shin DW, Cho J. et al. Prevalence predictors of anxiety and depression among family caregivers of cancer patients: A nationwide survey of patient-family caregiver dyads in Korea. Support Care Cancer, 2013Oct;21(10):2799-807.

28. Demirtepe-Saygili D, Bozo O. Correlates of Depressive and Anxiety Symptoms Among the Caregivers of Leukemic Child. J Clin Psychol Med Settings.2011 Mar;18(1):46-54.

29. Kim Y, Baker F, Spillers RL, Wellisch DK. Psychological adjustment of cancer caregivers with multiple roles. Psychooncology, 2006 Sep; 15(9), 795-804.

30. von Essen L., Sjoden PO, Mattson E. Swedish mothers and fathers of a child diagnosed with cancer--a look at their quality of life. Acta Oncologia, 2004; 43(5): 474-479.

31. Phillip Lanzkowsky. Manual of Pediatric Hematology and Oncology, 4th edition. Elsevier Academic Press, 2005, p.330-334 
32. Iqbal A, Siddiqui KS. Depression among parents of children with acute lymphoblastic leukemia. J Ayub Med Coll Abbottabad. 2002; 14(2):6-9.

33. Jie Chen, Yang Liu, Qingqing Cai, Yimin Liu, Tong Wang, Jingfeng Wang, Wei-qing Chen, Hui Huang. Depression in parents of children with leukemia in southern China accompanied by the prevalence of type D personality. Supportive Care in Cancer. May 2014, 22(5):1277-1286.

34. Sawyer G., Antoniou G., Toogood I. Rice M., Baghurst P. A. A prospective study of the psychological adjustment of parents and families of children with cancer. Journal of pediatrics and child health. 1993, 29(5):352-356

35. Shi L, Gao Y, Zhao J, Cai R, Zhang P, Hu Y, Li Z, Li Y, Prevalence and predictors of posttraumatic stress symptoms in parents of children with ongoing treatment for cancer in South China: a multi-centered cross-sectional study. Support Care Cancer. 2017 Apr;25(4):1159-1167.

36. Barrera M, Atenafu E, Doyle J, Berlin-Romalis D, Hancock K. Differences in mothers' and fathers' psychological distress after pediatric SCT: a longitudinal study. Bone Marrow Transplant. 2012 Jul;47(7):934-9.

37. Clarke NE, McCarthy MC, Downie P, Ashley DM, Anderson VA. Gender differences in the psychosocial experience of parents of children with cancer: a review of the literature. Psychooncology. 2009 Sep;18(9):907-15.

38. Pai AL, Greenley RN, Lewandowski A, Drotar D, Youngstrom E, Peterson CC. A meta-analytic review of the influence of pediatric cancer on parent and family functioning. J Fam Psychol. 2007 Sep;21(3):407-15.

39. Kazak AE, Alderfer M, Rourke MT, Simms S, Streisand R,Grossman JR. Posttraumatic stress disorder (PTSD) and posttraumatic stress symptoms (PTSS) in families of adolescent childhood cancer survivors. J Pediatr Psychol. 2004; 29:211-9

40. Frank NC, Brown RT, Blount RL, Bunke V. Predictors of affective responses of mothers and fathers of children with cancer. Psychooncology. 2001; 10:293-304.

41. Dunn MJ, Rodriguez EM, Barnwell AS, Grossenbacher JC, Vannatta K, Gerhardt CA, Compas BE. Posttraumatic stress symptoms in parents of children with cancer within six months of diagnosis. Health Psychol. 2012 Mar;31(2):176-85. 